J. Perinat. Med. 15 (1987) 429

\section{Consequences of asphyxia in surfactant deficiency}

\author{
Gösta Rooth ${ }^{1}$ and Ola Didrik Saugstad ${ }^{2}$ \\ ${ }^{1}$ Department of Obstetrics, University of Zurich, Switzerland \\ ${ }^{2}$ Department of Pediatrics, The National Hospital of Norway, Oslo, Norway
}

\section{Introduction}

Some of the physiological changes taking place during the transition from intra- to extrauterine respiration should first be considered as they constitute part of the mechanism also occurring during asphyxia.

\section{Transition from intra- to extrauterine life}

Expansion of the lung: There is at first a squeeze on the thorax and then a recoil. The latter depends partly on the tonus of the infant, and during severe asphyxia tonus is lacking.

Increase in pulmonary blood flow: When the pulmonary capillaries around the alveoli become filled with blood the vessels tend to straighten out, like a garden hose, contributing to the opening of the alveoli [8]. In the severely asphyxiated infant blood pressure is low and the filling and expanding force reduced.

Vasomotor effect of $\mathrm{Po}_{2}$ and $\mathrm{Pco}_{2}$ : Decrease in $\mathrm{Po}_{2}$, or decrease in $\mathrm{pH}$ leads to vasoconstriction in the lung $[4,14]$. In utero the low fetal $\mathrm{Po}_{2}$ prevents the fetal pulmonary bed to open up. There is a drastic increase in $\mathrm{Po}_{2}$ in the alveoli which is even larger than might be inferred from the data in most textbooks as the latter usually refer to $\mathrm{PaO}_{2}$ values in blood sampled below the ductus. Sampled above the ductus $\mathrm{PaO}_{2}$ increases even more rapidly. Fetal transcutaneous $\mathrm{Po}_{2}$ monitoring continued after delivery gave a mean value in 10 cases to $53 \mathrm{~mm} \mathrm{Hg} 10 \mathrm{~min}$ after birth. When $\mathrm{tcPo}_{2}$ was initiated soon after birth the mean value was $70 \pm 15 \mathrm{mmHg} 9$ min after birth in 63 infants [12]. In spite of birth asphyxia with delayed onset of respiration until $1.3 \mathrm{~min}$ after birth, there was a rapid increase in $\mathrm{Po}_{2}$ once respiration was above 40 breaths/min (figure 1). With the first breaths alveolar $\mathrm{Po}_{2}$ will probably increase to $130-140$ $\mathrm{mm} \mathrm{Hg}$ in the aereated parts of the lungs. Once $\mathrm{CO}_{2}$ enters the alveoli $\mathrm{Po}_{2}$ will of course be correspondingly lower and will stabilize at about 110 $\mathrm{mm} \mathrm{Hg}$. The high alveolar $\mathrm{Po}_{2}$ quickly leads to $\mathrm{PaO}_{2}$ increase and once this is above $40 \mathrm{~mm} \mathrm{Hg}$ the resistance in the peripheral circulation increases and that in the pulmonary circulation decreases. The higher the $\mathrm{FiO}_{2}$ the greater the blood content of the lung as exemplified from a study of newborn rats (figure 2). In the asphyxiated fetus $\mathrm{Po}_{2}$ will be less than $10 \mathrm{~mm} \mathrm{Hg}$. The relative increase in $\mathrm{Po}_{2}$ will therefore be at least $\mathbf{1 0}$ fold compared to the normal $3-5$ fold increase in vigorous infants. As figure 2 shows the filling with the lungs of blood increases with increase in $\mathrm{FiO}_{2}$ [13]. There is also a time factor to consider although its significance for the newborn infant is unknown. When a high $\mathrm{FiO}_{2}$ was maintained less than 4 hours the increase in lung weight at elevated $\mathrm{FiO}_{2}$ was smaller. The results shown in figure 2 were obtained after $4-7$ hours exposure of the newborn rats. If the exposure lasted more than 7 hours atelectasis and vascular collaps occurred [13].

The capability of the normal lung: Within $10 \mathrm{~min}$ after birth with a $\mathrm{FiO}_{2}$ of $0.75 \mathrm{PaO}_{2}$ may increase over $100 \mathrm{~mm} \mathrm{Hg}$ during one single inhalation [7] (figure 3). It cannot be excluded that similar drastic increases occur in the aereated and perfused parts of the lungs also in the asphyxiated infants who almost routinely are given $50-100 \%$ oxygen. Still, in all but the most severe cases will it probably be possible to increase $\mathrm{PaO}_{2}$ sufficiently by ventilation with air alone. It is unclear to which 


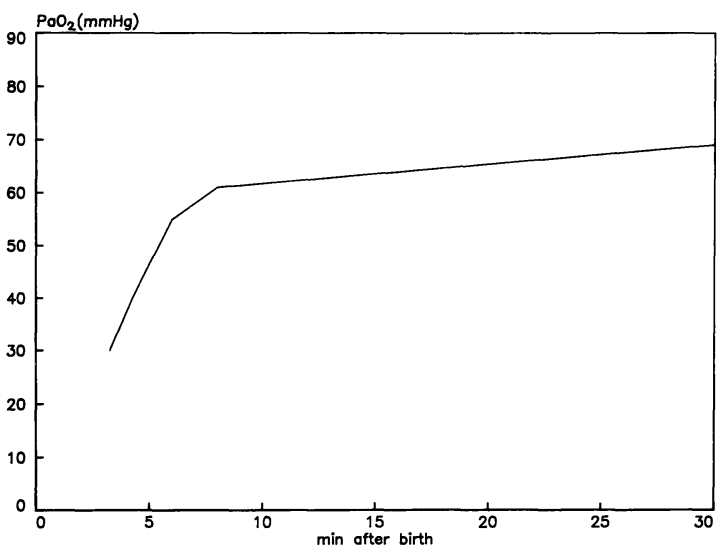

Figure 1. Increase in arterial $\mathrm{Po}_{2}$ in the aortic arch in a newborn infant with moderate neonatal depression; modified from ENGSTRŌM et al [2].

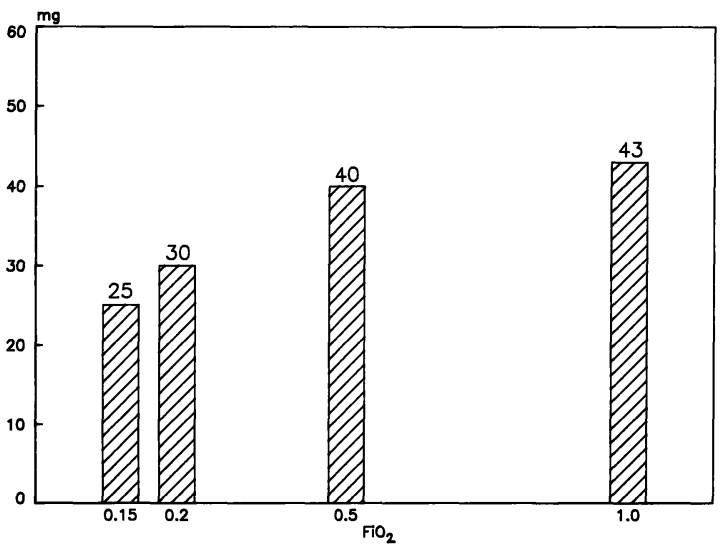

Figure 2. Mean weight of blood in lungs of newborn rats exposed to different $\mathrm{Fi} \mathrm{O}$; modified from RoOTH \& SJÖSTEDT [13].

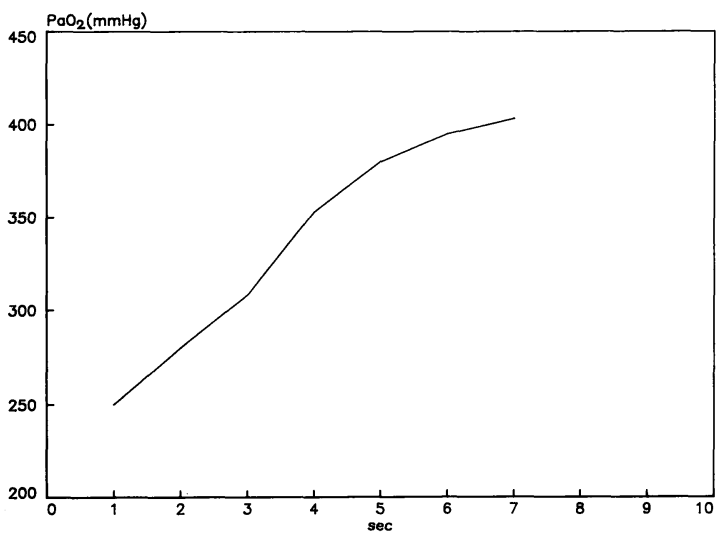

Figure 3. Increase in arterial $\mathrm{Po}_{2}$ in the aortic arch 10 min after birth of a healthy newborn infant exposed to a $\mathrm{Fi} \mathrm{O}_{2}$ of 0.75 . Each straigth part of the curve represents one inspiration; modified from HucH et al [7]. extent supplementary oxygen is needed. Usually RDS is preceded by asphyxia and the treatment of asphyxia is part of the complex and multifactorial pathophysiological background. We are between two dangers; the risk of progressive asphyxia on the one hand and the risk of iatrogenic distrubances on the other hand. The resuscitation with high concentrations of oxygen increases the possibility for increased oxygen radical production in the lungs and other organs. We are specially interested in free radical production through the hypoxanthine-xanthine oxidase system.

\section{Oxygen radicals and scavengers}

Oxygen radicals can be formed from many sources. The activated macrophage produces oxygen radicals and this could be a cause to tissue damage for instance in the lung. Another source of oxygen radicals is the hypoxanthine-xanthine oxidase system. This system is particularly important in asphyxiated and post-asphyxiated newborn infants who usually have high concentrations of hypoxanthine in the tissues and body fluids [15]. Free radicals are compounds, molecules or atoms, with one unpaired electron in its outer electron orbit. They are highly unstable and reactive, and they can damage all cell membranes in the organism. Oxygen radicals are produced when oxygen is reduced univalently to water, (for reference see the review [16]). The superoxide radical and particularly the hydroxyl radical are most toxic to the cells. When hypoxanthine is oxidized to uric acid a small part of the oxygen involved is reduced to the superoxide radical. Hydrogen peroxide also is formed and then the hydroxyl radical can be formed as well:

$$
\begin{array}{ll}
\text { Hypoxanthine } \\
+2 \mathrm{O}_{2}+\mathrm{H}_{2} \mathrm{O}
\end{array} \stackrel{\text { xanthine oxidase }}{\longrightarrow} \begin{aligned}
& \text { Uric acid } \\
& +\mathrm{H}_{2} \mathrm{O}_{2}+\mathrm{O}_{2}^{-}
\end{aligned}
$$

The organism has defense mechanisms against oxygen radicals, such as superoxide dismutase (SOD) and catalase. The SOD content of the lung of rat fetuses increases toward term [6, 22]. Lung tissue of the rat neonate is capable of rapidly enhancing SOD activity when oxygen is administered $[1,5]$. This response is age-dependant with maximum effect occuring in ten-day-old animals. If these data are applicable to the human, preterm infants are more vulnerable to oxygen radicals than the term ones. 


\section{Oxygen radicals and surfactant}

In hypoxia there is an accelerated breakdown of AMP to its end product hypoxanthine. This is illustrated in figure 4. Provided oxygen is present the hypoxanthine normally formed is either oxidized to uric acid or metabolized to IMP through the so called salvage pathway. Both of these pathways are blocked in hypoxia and hypoxanthine is accumulated [18]. Particularly after hypoxia, when there is high concentration of hypoxanthine, large amounts of oxygen radicals are produced during resuscitation and the generation of free radicals is further increased with high concentrations of oxygen. The combination of hypoxanthine and oxygen in the posthypoxic reoxygenation period may thus be detrimental [17]. This hypothesis for the pathogenesis of posthypoxic reperfusion damage has later been accepted and further developed by other authors $[10,11]$. We have studied the effects of this system on the rat lung [21]. Hypoxanthine was infused intravenously in rats breathing $100 \%$ oxygen. After 2 days the rats were sacrificed and the lungs were investigated both biochemically and morphologically. The typical changes found were vascular engorgement, hemorrhage and edema. Further, in lung lavage fluid there was a manifold increase in total protein and alpha-1-antitrypsin levels. The surfactant phospholipids revealed a normal pattern. The function of the surfactant when studied with a pulsating bubble surfactometer [3] showed that the minimal surface tension was increased to such an extent that the surfactant function was completely abolished. These findings were in contrast to what was found in control animals treated with $100 \%$ oxygen alone or hypoxanthine infused rats breathing room air [21]. As surfactant is quite resistant to oxidization it seems that the surfactant was inactivated by protein. We also gave guinea pigs one unit xanthine oxidase with one $\mathrm{ml}$ normal saline (approximately $3 \mathrm{ml} / \mathrm{kg}$ ) [19]. A dramatic decrease in lung complicance to in mean $15.8 \%$ of the initial values was found when xanthine oxidase was given. To our surprise saline alone also reduced compliance substantially to $38.9 \%$ of the initial values, however significantly less than when given together with xanthine oxidase. SOD together with xanthine oxidase prevented the xanthine oxidase effect but not the saline effect and compliance fell to in mean $35.5 \%$ of the initial levels when 20,000 U SOD were given together with one $\mathrm{ml}$ saline (figure 5). Saline alone therefore seems to have a severe effect on lung compliance

\section{ADENINE NUCLEOTIDE METABOLISM}

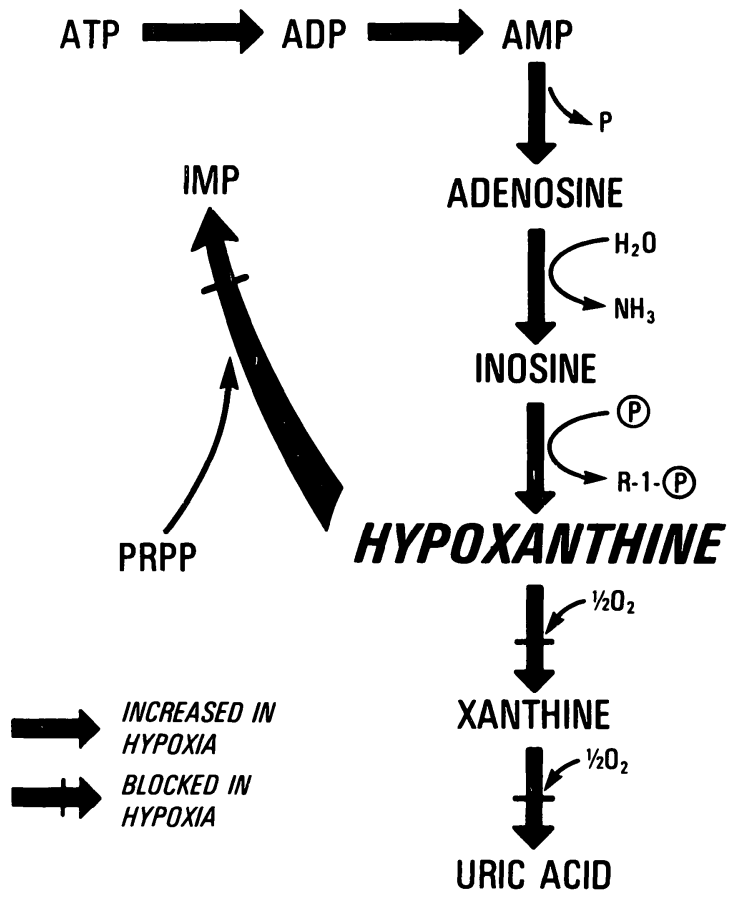

Figure 4. Hypoxanthine metabolism in normoxia and hypoxia. Hypoxanthine is the breakdown product from AMP. In hypoxia oxygenation to uric acid is stopped as well as the salvage back to IMP. Therefore hypoxanthine is accumulated; from [18] in agreement with figures $1-3$.

\section{Lung}

Compliance

(\% change)

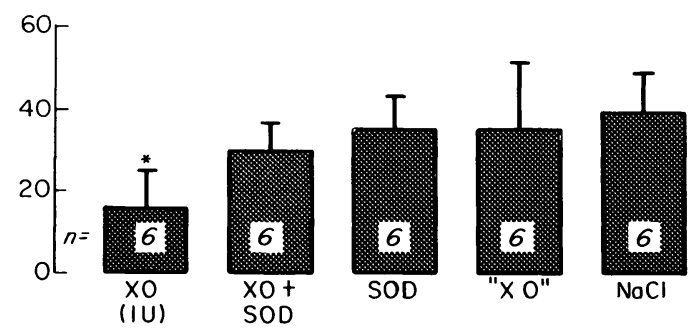

Figure 5. Percentage change from initial values of lung compliance of guinea pigs 20 minutes after giving 1 unit of xanthine oxidase in $1 \mathrm{ml}$ saline intratracheally, xanthine oxidase + superoxide dismutase in saline or saline alone. Superoxide dismutase $(20000 \mathrm{U})$ and inactivated xanthine oxidase, "XO" served as controls; from [19]. 
in guinea pigs on intermittent positive pressure ventilation, but no such effect was found when the animals were ventilating spontaneously. This phenomenon probably occurs in the human as well. If so the volumes of saline applied into the trachea of babies ventilated with IPPV as "placebo" in clinical surfactant studies may seriously effect the results and expose the sick infant to additional risks. Xanthine oxidase seems to reduce lung compliance through oxygen radicals since this effect was prevented by SOD. In the lung with low compliance there is every reason to assume that endogenous hypoxanthine is elevated and xanthine oxidase may be present, for instance after leakage from the liver. We therefore believe this model can give us information concerning acute lung damage seen in babies with RDS. The immediate necrosis of bronchial endothelium observed in RDS could be due to production of free oxygen radicals by a direct effect on the cells and indirectly by inactivation of the surfactant system as described. Lung compliance of xanthine oxidase treated lungs is restored by giving natural surfactant [9]. The hypoxanthinexanthine oxidase system also has a long term effect. One single dose of xanthine oxidase injected intratracheally in guinea pigs resulted in a significant decreased lung compliance 14 days after the injection [20].

\section{Summary}

Consequences of asphyxia in babies with surfactant deficiency are discussed. Several important points concerning transition from intra- to extrauterine life are underlined. In asphyxia large amounts of hypoxanthine are formed and in the postasphyxic period when high concentrations of oxygen are given large amounts of oxygen radicals are produced. Experimentally we have shown that such radicals produce lung engorgement, hem-

\section{Conclusions}

A series of factors normally taking place during transition from intra- to extrauterine life are exaggerated in asphyxiated infants and the stage is set for pulmonary damage. We have specially been pointing out the dangers of giving $100 \%$ oxygen. The oxygen radicals seem to have a direct effect through inactivation of the lung surfactant. These considerations might have therapeutical implications:

- Although effective measures must be taken to eliminate an existing asphyxia the oxygen concentrations should be kept as low as possible.

- Instillation of liquids in the trachea should only be part of a necessary therapeutic procedure.

- A systematic study of the effect of superoxide dismutase and other scavengers of free radicals should be made.

- Monitoring the hypoxanthine concentration using a fast method, is of value in the treatment of asphyxia.

Several of these points need careful study both in the research laboratories and in well planned, if possible, randomised studies.

orrhage and edema. Further they inactivate surfactant. Oxygen radicals also reduce the lung compliance dramatically in animal experiments. Saline alone given intratracheally to animals ventilated artifically will also reduce lung compliance. It is therefore not recommended to give saline intratracheally as a placebo in surfactant trials.

Keywords: Asphyxia, hypoxanthine, oxygen radicals, RDS, surfactant deficiency.

\section{Zusammenfassung}

\section{Vorgehen bei Asphyxie und Surfactantmangel}

Es wird das Vorgehen bei asphyktischen Neugeborenen mit Surfactantmangel diskutiert. Dabei werden die wichtigen Punkte, die den Übergang vom intra- zum extrauterinen Leben betreffen, unterstrichen. Während der Asphyxie wird Hypoxanthin in großen Mengen gebildet und nach der asphyktischen Periode werden, wenn Sauerstoff in hoher Konzentration gegeben wurde, reichlich $\mathrm{O}_{2}$-Radikale freigesetzt. Diese können, wie experimentell bewiesen wurde, zu Aufblähung, Blutung und Ödem in den Lungen führen. Darüber hinaus inaktivieren sie den Surfactant. In Tierexperimenten wurde gezeigt, daß $\mathrm{O}_{2-}$ Radikale in drastischer Weise die Compliance vermindern. Bei künstlich beatmeten Tieren führt eine intratracheal applizierte $\mathrm{NaCl}$-Lösung ebenfalls zu einer herabgesetzten Lungencompliance. Wir raten deshalb davon $\mathrm{ab}$, bei Surfactant-Versuchsreihen $\mathrm{NaCl}$ intratracheal als Placebo zu verwenden.

Schlüsselwörter: Asphyxie, Hypoxanthin, $\mathrm{O}_{2}$-Radikale, RDS, Surfactantmangel. 


\section{Résumé}

Consequences de l'asphyxie en cas de déficience en surfactant

On discute les conséquences de l'asphyxie chez les enfant ayant une déficience en surfactant. Plusieurs points importants concernant la transition de vie intra-utérine en vie extra-utérine sont soulignés. En cas d'asphyxie des quantités importantes d'hypoxanthine se forment et en période post-asphyxique lorsqu'on fournit de l'oxygène à concentrations élevées, de nombreux radicaux oxygène se produisent. Nous avons montré expérimentalement que de tels radicaux provoquent un encombrement pul- monaire, des hémorragies et de l'œdème. En outre, ils inactivent le surfactant.

Les radicaux oxygène diminuent également la compliance pulmonaire du façon majeure au cours des expériences animales. La compliance pulmonaire est également diminuée chez des animaux ventilés artificiellement chez lesquels on instille du $0,9 \% \mathrm{NaCl}$ isolément en intra-trachéal. Ainsi, il n'est pas recommandé d'instiller du $0,9 \% \mathrm{NaCl}$ en intra-trachéal comme placebo dans les essais sur le surfactant.

Mots-clés: Asphyxie, déficit en surfactant, hypoxanthine, radicaux oxygène, S. D. R.

\section{References}

[1] Autor AP, L Frank, RJ Roberts: Developmental characteristics of pulmonary superoxide dismutase: relationship to idiopathic respiratory distress syndrome. Pediatr Res 10 (1976) 154

[2] Engström L, P Karlberg, G Rooth, R Tunell: The onset of respiration. Association for the aid of crippled children, New York 1966

[3] ENHöRnING G: A pulsating bubble technique for evaluating pulmonary surfactant. J Appl Physiol 99 (1977) 53

[4] EULER vON US, G LiLJeSTRAND: Observations on pulmonary arterial blood in cat. Acta Physiol Scand 12 (1946) 301

[5] Frank L, AP Autor, RJ Robert: Oxygen therapy and hyaline membrane disease: The effect of hyperoxia on pulmonary superoxide dismutase activity and the mediating role in plasma and serum. $J$ Pediatr 90 (1977) 105

[6] Gerdin E, O Tyden, UJ ErIKson: The development of antioxidant enzymatic defense in the perinatal rat lung: Activities of superoxide dismutase, gluthathion peroxidase and catalase. Pediatr Res 19 (1985) 687

[7] Huch A, R Huch, G Rooth: Monitoring the intravascular $\mathrm{PO}_{2}$ in newborn infants. $\mathrm{J}$ Perinat Med 1 (1973) 53

[8] JÄYKKÄÄ S: Capillary erection and lung expansion. An experimental study of the effect of liquid pressure applied to the capillary network excised fetal lung. Acta Paediatr Scand [Suppl] 112 (1956) 1

[9] LACHMANN B, OD SAUGSTAD, W ERdman: Effects of surfactant replacement on respiratory failure induced by free oxygen radicals. In: SchlaGG, LH RED (eds). Progress in clinical and biological research, vol 236 B. Alan R. Liss, N
[10] MC CORD J: Oxygen derived free radicals in post ischemic tissue injury. N Engl J Med 312 (1985) 159

[11] Parks DA, GB Bulkley, DN Granger: Role of oxygen radicals in shock, ischemia and organ preservation. Surgery 99 (1983) 428

[12] Rooth, G, O Fall, H Schachinger, A Huch, R Huch: Continuous transcutaneous $\mathrm{PO}_{2}$ measurement in the newborn immediately after delivery. In: SaKamoto S, M Tojo (eds): Gynecology and Obstetrics International Congress series No 512. Proceedings of the 1X World Congress of gynecology and obstetrics. Excerpta Medica, Amsterdam 1979

[13] Rooth G, S SJöstedT: Lung weight and oxygen tension in newborn rats. Etudes Néo-Natales 7 (1958) 121

[14] RUDOLPH AM: Regulation of pulmonary circulation in respiratory distress syndrome. In: RAIVIo KO, N HallmanN, K Kouvalainen, I VälimäKI (eds): Respiratory distress syndrome. Academic Press, London 1984

[15] SAugstad OD: Hypoxanthine as a measurement of hypoxia. Pediatr Res 9 (1975) 158

[16] Saugstad OD: Oxygen radicals and pulmonary damage. Pediatr Pulmonol 1 (1985) 167

[17] Saugstad OD, AO AASEN: Plasma hypoxanthine levels as a prognostic aid of tissue hypoxia. Eur Surg Res 12 (1980) 123

[18] Saugstad OD, L Gluck: Plasma hypoxanthine levels in newborn infants: A specific indicator of hypoxia. J Perinat Med 10 (1982) 266

[19] Saugstad OD, M Hallman, G Becher, A Oddoy, B LACHMANN: Protective effects of superoxide dismutase on severe lung damage caused by xanthine oxidase. Pediatr Res 18 (1894) 802 
[20] Saugstad OD, G Becher, M Grossman, G MerKER, A ODDOY, B LACHMANN: Acute and chronic effects of xanthine oxidase on lung thorax compliance in guinea pigs. Intensive Care Med 13 (1987) 30

[21] Saugstad OD, M Hallman, J Abraham, CG Cochrane, B EpsteIn, L Gluck: Hypoxanthine and oxygen induced lung injury: A possible basic mechanism of tissue damage? Pediatr Res 18 (1984) 501
[22] Tanswell AK, BA Freeman: Pulmonary antioxidant enzyme maturation in the fetal and neonatal rat. 1. Developmental profiles. Pediatr Res 18 (1984) 584

Gösta Rooth

Öfre Slottsgatan 14

S-752 35 Uppsala, Sweden 